JANINA STANKIEWICZ

PATRYCJA ŁYCHMUS

HANNA BORTNOWSKA

\title{
Autonomous teams as \\ a way to increase the engagement of nonprofit members (case study)
}

\section{Introduction}

Engagement ${ }^{1}$ enjoys considerable interest

Prof. Janina Stankiewicz, University of Zielona Góra,

Faculty of Economics and Management,

Poland,

ORCID: 0000-0001-6199-0210.

Patrycja Łychmus, Ph.D. Eng.,

University of Zielona Góra,

Faculty of Economics and Management,

Poland,

ORCID: 0000-0003-3599-1046.

Hanna Bortnowska, Ph.D. Eng.,

University of Zielona Góra,

Faculty of Economics and Management,

Poland,

ORCID: 0000-0002-7327-7524. among theoreticians and practitioners of management science ${ }^{2}$. In addition, this concept in the English literature is also referred to as commitment or involvement ${ }^{3}$ (Łochnicka, 2015, cf. Mrówka, 2010). Commitment refers primarily to the attachment and sense of belonging of an employee to the organization. According to J.P. Meyer and N.J. Allen (1991), the following types of commitment can be distinguished: affective (emotional) commitment, duration commitment (associated with the calculation approach to staying in the organization), and normative commitment (conditioned by social norms). Commitment, therefore, is determined by subjective (resulting from individual characteristics of the employee and

1 In the Polish Language Dictionary, the Polish term "zaangażować się" (lit. „engaged oneself”) means ",to take active (mainly emotionally) participation in an activity, undertaking, work, project" (https://sjp.pl/zaangazowac+, 23.05.2018 - access date).

2 The notion of employee engagement can be traced back to classical theories of motivation: D. McGregor, F. Herzberg, C. Alderfer, R. Hackman and G. Oldham, A. Maslow (Mrówka, 2010).

3 The results of the Google Scholar database review showed that the most publications in the analyzed area include the term "involvement" in the title $(341,000)$. There are less papers in which the terms "engagement" $(149,000)$ or "commitment" $(103,000)$ appear in titles (https://scholar. google.pl/, 07/05/2019). The number of positions in which that issue is linked (in the title) with work, employee and/or organization is adequate: 1737, 5343 and 5168. 
her/his professional circumstances) as well as cultural factors (related to social norms and customs) (Eochnicka, 2015). Members involved in this way are proud of belonging to the organization, are loyal to it, and identify with its goals (Scholl, as cited in: Łochnicka, 2015).

Involvement, in turn, assumes direct participation, or more specifically - it involves employees in the process of solving problems and making organizational decisions, thus increasing the scope of their autonomy (Sofijanova and ZabijakinChatleska, 2013; cf. Lawler, 1994; Pun et al., 2001). Such employees are informed about important issues affecting their functioning in the current workplace, their needs are recognized, they are provided feedback on results, plus they are encouraged to actively participate in the process of shaping their professional situation within the company (cf. Łochnicka, 2015).Employers, in order to encourage involvement among their employees, can, for example, appoint autonomous teams (Sofijanova and Zabijakin-Chatleska, 2013), which perform interdependent tasks and take over a number of duties from their supervisor. These tasks are related, among others, to: planning work, budgeting, resource allocation, work schedule, assigning tasks to team members, making operational decisions, coordinating activities with clients, suppliers or other parts of the organization (cf. Mullins, 2005, Torrington et al., 2002). Members of such teams decide about their composition at their own discretion and evaluate their work independently (Sofijanova and Zabijakin-Chatleska, 2013).

Last but not least, engagement is defined by R.J. Vance (2006) as an emotional relationship between the employee and the company, expressed in one's identification with the company's goals and values. A similar view is held by B. Skowron-Mielnik (2014), for whom an engaged member of the organization not only fulfills her/his daily professional duties, but also shows concern for the company's growth and future, additionally subscribing to its mission and goals.

In theliterature, a correlation is observed between involvement and engagement. Namely, it is believed that the former facilitates the shaping of the latter (Robbins and Judge, 2013; cf. Harter et al., 2002; Maslach and Leiter, 2008). This approach was taken in this article and it became an inspiration for undertaking research on the engagement of members in a nonprofit organization, relying on a case study of the Association of Friends of Persons with Down Syndrome (Polish: Stowarzyszenie Przyjaciót Osób z Zespołem Downa, SPOzZD), in which there were significant shortages in this respect.

A lot of theoretical and empirical work has been carried out in the field of engagement. The analysis of the GoogleScholar database showed that researchers involved in the issue of engagement (in the three approaches mentioned above) 
reflect on its determinants (e.g. Anitha, 2014; Croston, 2008; Smythe, 2009) and analyze the relationship between that phenomenon and the functioning of organizations (e.g. Gruman and Saks, 2011; Harter et al., 2002) and its members (e.g. Macey and Schneider, 2008; Salanova et al., 2005; Stankiewicz and Moczulska, 2014). Some scientists prepare engagement measurement tools and apply them in practice (e.g. Schaufeli and Bakker, 2003; Soane et al., 2014). The titles of a few publications contain information about the fact that their authors take up the problem of engagement in nonprofit entities in their content. In the case of each of the analyzed terms (engagement, involvement, commitment) and keywords referring to entities of the third sector ${ }^{4}$, this percentage did not exceed $0.2 \%$. The works in this area concern, among others, developing the engagement of leaders of non-governmental organizations (e.g. Freeborough and Patterson, 2015), volunteers (e.g. Alfes et al., 2016; Stankiewicz et al., 2018), models of employee engagement (e.g. Park et al., 2018) or factors and consequences of engagement in such subjects (e.g. Akingbola and van den Berg, 2019).

The aim of the article is to determine the reasons for the low engagement among SPOzZD members, to identify their expectations towards the functioning of the Association as well as to indicate activities that could encourage further engagement of these members, which can be implemented by representatives of the Board. To this end, a case study was conducted. This article contains an overview of the prepared case study and a brief description of the process of its development.

\section{Association of Friends of Persons with Down Syndrome in Zielona Góra - a profile}

The Association of Friends of Persons with Down Syndrome has been active in Zielona Góra since 1999 and associates over fifty families (90 parents/ guardians of persons with Down Syndrome belong to the Association). Its activity encompasses the area of Lubuskie Province. The Association was founded as a result of the growing needs of parents of children with Down syndrome associated with caring for their children's health. The parents thought that only by institutionalizing their activity could their children more fully enjoy the rights and privileges of disabled people, by means of facilitating

4 The following keywords were used to review that database: engagement, involvement, commitment, nonprofit, non-profit, NGO, non-governmental, nongovernmental, voluntary organization, third sector.

Autonomous teams as a way to increase the engagement of nonprofit members 
the obtaining of funds for the necessary forms of support. The rehabilitation needs are huge. Down Syndrome (Trisomy 21) manifests itself as a syndrome of congenital defects. Some of them are only dysmorphic features, which do not decrease the quality of life, but they are accompanied by serious defects. Patients may experience: heart defects, hearing disorders, short-headedness, tooth hypoplasia, cataracts and other sight disorders, digestive system defects, coeliac disease, abnormalities in skeleton structure, changes in the sexual and urinary system, fertility disorders, thyroid disorders, epileptic attacks and many others. These numerous defects, such as congenital heart defects, usually require surgical treatment. In addition, people with Down Syndrome have limp muscles, which means that they often do not close their mouths and expose their tongue, have a delayed motor development, sometimes not reaching full physical efficiency. All patients suffer from congenital immunodeficiency, which significantly increases the frequency of various infections. They tend to develop leukemia of various types. A permanent feature of this genetic defect is a mental disability (from mild to severe). People with a mild degree of intellectual disability are doing well in everyday life, so they only need a little help from their caregiver, e.g. to fill in forms. If someone has a severe intellectual disability, he needs help in every area of his life, e.g. while washing, dressing, shopping. People with mental and physical disabilities sometimes require 24-hour care because they are unable to cope with the simplest, everyday activities. Down Syndrome is incurable. Therefore, in addition to multifaceted rehabilitation, therapies are used to improve the quality of life of patients. The aim of the Association is to provide assistance to people with intellectual disabilities in all areas of life. The care is provided to children and youth with Down Syndrome as well as to their families or legal guardians, i.e. people at risk of marginalization and social exclusion. The organization promotes the idea of supporting the autonomy and teaching independence to the disabled, with a view to increasing their participation in social life. Persons acting on behalf of the Association wish to improve the image of people affected by Down syndrome and show them through the prism of broadly understood activity. The organization's statutory activity includes, among others: organization of rehabilitation, therapeutic and educational exercises as well as cultural, integration and recreational activities. In addition, in 2015 the Association set up a Support Group for Parents of Persons with Down Syndrome. A range of support mechanisms this wide creates an opportunity not only for the multidirectional development of persons with Down syndrome, but also for their inclusion in social life, which 
will then raise their self-esteem. However, this requires dedicated engagement at social level from all members.

\section{Methods}

In the course of preparing research works to achieve the goals assumed, the inductive case study approach proposed by W. Czakon (2006, p. 10) ${ }^{5}$ was adopted, including the following stages ${ }^{6}: 1$. Research question. 2 . Case selection. 3. Development of data collection tools. 4. Conducting field research. 5. Data analysis. 6. Forming generalizations. 7. Confrontation with the literature. 8. Closing the study - generalization.

No case scenario was assumed a priori (meaning, no hypotheses were formulated), but questions were asked to establish its characteristics, which is an important feature of inductive research (Dondajewska, 2016). It should also be mentioned that the first two stages proposed by W. Czakon were followed in reverse order, i.e. case selection preceded the formulation of research questions. This was justified by the fact that the need to solve the problem was reported by representatives of the Board of the Association of Friends of Persons with Down Syndrome in Zielona Góra (key informants), who inspired the research, which was eventually carried out in 2017. As argued by the key informants during the interviews, the research was to address the low engagement of the members of the Association in its activities. It should be added that the decision to apply the case study method was justified by the search for "the meanings and content of events and investigating the characteristics of the course of processes" (Dondajewska, 2016, p. 47), which is a common scenario in this research method. Moreover, in the literature on management, case studies are generally thought

5 The case study method involves research on a single or multiple case studies. As far as management science, case study is "a detailed description, usually of an actual economic phenomenon - e.g. an organization, management process, its elements or the organization's environment - whose aim is to formulate conclusions about the causes and results of its course" (Grzegorczyk, 2015, p. 10). Similarly to W. Czakon (2015, p. 190), the case was considered to be "a single research object, recognized for a specific purpose, located in a specific place and time, taking into account the circumstances relevant to it".

6 The procedure for preparing the case study was also inspired by that proposed by N. Skorek et al. (2010), covering the following seven stages: 1. Determining the problem area and goals of the case study, 2. Determining the subject of the case study, 3. Establishing contact with the subject of the case study, 4 . Determining the structure of the case study, 5. Collecting information for the case study, 6. Verification and evaluation of collected research material. 7. Writing the case study.

Autonomous teams as a way to increase the engagement of nonprofit members 
to serve three goals: theory-building, theory-testing, and practical (Grzegorczyk, 2015). The practical goal, which was adopted in this study, was of hands-on nature, including training, and it served primarily to "understand the course of the decision-making process in the organization, carried out under specific conditions. This provides the basis for using the case study method to make managerial decisions in conditions similar to those presented in the case study. Such case study arrives at findings that can be applied in practice. It contains a description of the problem under investigation and the process of solving it, thus explaining certain desired effects of the decisions being made" (Grzegorczyk, 2015, p. 11).

In the course of own research, three research problems were outlined: 1 . What are the reasons for the low engagement of the members of the Association to work for the nonprofit organization which they belong to? 2. What are the expectations of the members related to the functioning of the analyzed entity? 3. What actions can the representatives of the Board implement to increase the engagement among members? To answer these questions, a number of data collection tools were developed: an interview scheme with representatives of the Board, a report template followed by a survey questionnaire ${ }^{7}$ addressed to all members of the Association (taking into account results from previous interviews), and finally a form for coding and analyzing respondents' statements. These tools were used during the field research stage, which was carried out in February 2017. The interviews conducted with the representatives of the Board (2 persons President and Vice-President) took the form of a free interview. It was considered that only this research technique creates a chance to obtain information that is not falsified and at the same time has a high emotional potential, which allows for taking into account in further analyses the specificity of functioning of families with a member who suffers with Down Syndrome. To encourage members of the Association to participate in the survey, it was emphasized that it was being conducted in response to their low engagement, attempting to understand the reasons for this situation, and that it was prompted by the need to make changes in the field of forms of cooperation between them and the Board. Nevertheless, the level of participation in the survey did not exceed $43.75 \%$ (90 questionnaires were distributed to all parents and guardians of the Association, 39 forms were returned). The other members refused to take part, either without giving a reason

7 The questionnaire contained 13 questions: 9 closed and/or semi-open (one- and multiple-choice) and 4 open. The ordinal and Likert scales were used. 
or by bringing up lack of time or insufficient knowledge about the functioning of nonprofit entities.

The implementation of the research and the analysis of results allowed to formulate generalizations regarding the reasons of the low involvement of the members of the surveyed organization and their expectations regarding the functioning of the Association. These findings are presented further down in this article, having been confronted with the available literature in search of possible answers to the questions posed at the outset of the research procedure. A proposed solution to the problem was put forward and implemented in the analyzed entity.

The result of the work was the preparation of a case study. In line with recommendations put forward by N. Skorek et al. (2010), the study consisted of: an introduction (in which the problem was signaled, sources of information were indicated, and a brief description of the organization was presented), individual chapters (concerning specific problems identified in the analyzed entity - causes and consequences of low involvement of the members of the Association, potential sources of their satisfaction, directions of their future work for the Association), references, as well as questions inspiring readers to seek solutions. An overview of the prepared study is presented in this article.

\section{Reasons for the low engagement of SPOzZD members and their expectations towards the organization}

Field research (interview, survey) revealed the passivity of the majority (97\%) of members of the Association. Most did not show any initiative whatsoever, avoided teamwork, did not take responsibility for planning, organizing, implementing or monitoring the organization's activities, reluctantly joined in expanding the offer for beneficiaries. Participants also did not demonstrate a sense of community. Such attitudes and behaviors may have been the result of the difficult situation of families affected by their child's disability, which forces their parents/legal guardians to focus on improving the child's very existence. On the basis of the interviews with the representatives of the Association's Board it was established that on the one hand there are problems with maintaining the health of such a person, his or her rehabilitation, which often determines/ restricts the actions of all family members, forcing them to make various kinds of "sacrifices" (e.g. resignation from professional career, limitation of entertainment, change in the structure of expenses, etc.). On the other hand, the fact of having to care for a child with Down Syndrome often arouses a sense

Autonomous teams as a way to increase the engagement of nonprofit members 
of injustice among parents or guardians discussed during interviews, reduces their subjective level of satisfaction with life and, as a result, gives rise to regret leading to the manifestation of claim attitudes and low engagement with them. As the President of the Board stressed, the functioning in the Association is perceived by those people more as an "inevitable necessity" rather than an opportunity for self-actualization, improvement or a chance to do something good. Making their attitude towards the Association go from passive to active would require overcoming psychological boundaries, extra effort and openly sharing their problems (building relationships with volunteers, representatives of local authorities, donors, etc.). Until now, these efforts have been negligible, which significantly hampered the functioning of the analyzed nonprofit entity.

During interviews with representatives of the Board, it was also determined that the specificity of functioning of the organization (e.g. lack of financial resources for achieving other goals other than statutory, limited time resources among member, flat organizational structure) resulted in some of the actions supporting members' involvement (training, career development, financial incentives, improvement of physical working conditions, etc.) being impossible to apply, while others (e.g. intensified interpersonal communication, appeals, requests for cooperation and help, strategies for achieving common goal and potential benefits, etc.) - increased them only slightly ${ }^{8}$.

In the course of the analysis of the survey results, it was noted that most respondents $(92.5 \%)$ expressed the opinion that the Association could potentially meet their expectations. More than half, meanwhile, wanted their children to attend revalidation classes of an educational, therapeutic and behavioral nature, conducive to the development of social, emotional and physical skills. Respondents were particularly interested in the participation of their children in rehabilitation classes and aquatic therapy according to Halliwick's concept $(57.5 \%)$, music therapy $(42.5 \%)$ and/or performing arts $(37.5 \%)$. It can be thus said that the course of action adopted by the current Board took root, given that expectations indicated by the surveyed members were included in the Association's most recent "catalog of services".

Respondents were also asked to come up with ideas for financing the indicated undertakings. However, they failed to offer any new solutions. Implementation of some of the proposals would require substantive skills and time investment,

8 The list of potential activities to stimulate and develop employee engagement was developed based, among others, on: D. Croston (2008), M. Juchnowicz (2010), J. Purcell (1993), S.P. Robinson et al. (2004), T.A. Kochan and L. Dyer (1993). 
while others would involve a small amount of time and little engagement. Some respondents wanted to keep building on the potential of two of the Board members, without much initiative on their own part. This is evidenced by the fact that the largest number of respondents indicated as a source of financing their ideas funds obtained through: public contests announced by the City Hall, Marshal Office, ROPS, etc. (52.50\%) or participation in the plastic cap recycling campaign $(52.50 \%)$. It should be noted that, until now, projects have been (successfully) developed by the two people from the Board, who invest to this end a lot of their private time, energy and knowledge and who in doing so "relieve" from this obligation the remaining members. On the other hand, collecting plastic caps did not require significant time or competence outlays, but rather, it was the result of everyday functioning.

The limited engagement to solving the Association's financial problems was confirmed by subsequent research findings. Areas of activity were identified which members would be most willing to join. Most (40.5\%) signed up for helping in the setting up of a Christmas market. One in three $(31 \%)$ considered collecting plastic caps and similar initiatives, while relatively fewer people were interested in other areas of involvement, such as: participation in a Support Group (14.3\%), joining a $1 \%$-tax claim campaign $(11.9 \%)$, or organizing thematic events $(11.9 \%)$. Even fewer respondents $(9.5 \%)$ would like to get involved in fundraising, and only a handful - in organizing hands-on workshops for younger children (e.g. from music therapy) or joint integration events (e.g. picnics) $(4.8 \%$, respectively).

In light of these findings, changes were proposed in the area of work organization at the Association, namely autonomous teams were appointed. Attention was focused on determinants of engagement such as: creating the opportunity for members to participate in managing the organization and making relevant important decisions, engagement at work aligned with their preferences, instilling the attitude of shared responsibility, promoting teamwork, building interpersonal relationships marked by openness and mutual trust, providing conditions for experimenting, making new attempts and generating solutions without worrying about the consequences of possible mistakes and failures.

\section{Autonomous teams ${ }^{9}$, the process of their creation}

The review of literature on teamwork in nonprofit organizations, available in the EBSCO and Google Scholar databases - originally conducted in 2017

9 In the literature, the term "autonomous groups" is used more often, but in this article, the term "team" is preferred to emphasize the need for cooperation between their members.

Autonomous teams as a way to increase the engagement of nonprofit members 
and updated on 12 December 2018 - revealed an important research gap. One reviewed publication was identified (Macdonald et al. 2002), containing in the title both of the following expressions: "teamwork" (team work), and "nonprofit" / "NGO" / "non-governmental" / "third sector". The article explored the topic of necessary cooperation between various entities (including nonprofit organizations) regarding the creation and provision of psychological health services. In fact, there are many studies on teamwork in business organizations (table 1).

An analysis of data contained in these bases shows that there are relatively few peer-reviewed scientific papers including in the title the term "autonomous teams" / "autonomous groups" or its synonyms.

Table 1. Number of (reviewed) publications on "autonomous teams" and three sample synonyms (1980-2018)

\begin{tabular}{|c|c|c|c|c|c|}
\hline \multirow{2}{*}{\multicolumn{2}{|c|}{$\begin{array}{l}\text { Synonyms of the term } \\
\text { "autonomous teams" }\end{array}$}} & \multicolumn{2}{|c|}{ EBSCO } & \multicolumn{2}{|c|}{ Google Scholar } \\
\hline & & $\begin{array}{l}\text { Number of } \\
\text { reviewed } \\
\text { publications } \\
\text { including } \\
\text { the term in } \\
\text { the title }\end{array}$ & $\begin{array}{l}\text { Number of re- } \\
\text { viewed publi- } \\
\text { cations includ- } \\
\text { ing the term in } \\
\text { the content of } \\
\text { the article }\end{array}$ & $\begin{array}{l}\text { Number } \\
\text { of publica- } \\
\text { tions in- } \\
\text { cluding the } \\
\text { term in the } \\
\text { title }\end{array}$ & $\begin{array}{l}\text { Number of } \\
\text { publications } \\
\text { including } \\
\text { the term in } \\
\text { the content } \\
\text { of the article }\end{array}$ \\
\hline \multicolumn{2}{|c|}{ "autonomous teams" } & 6 & 1416 & 41 & 4.460 \\
\hline \multicolumn{2}{|c|}{ "autonomous groups" } & 12 & 3410 & 36 & 11.500 \\
\hline \multirow{6}{*}{ 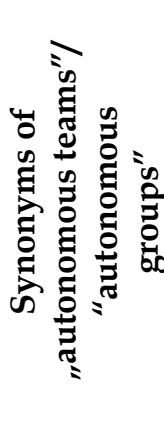 } & "self-managed teams" & 89 & 3556 & 135 & 10.500 \\
\hline & "self-managed groups" & 7 & 667 & 7 & 1.800 \\
\hline & "self-directed teams" & 17 & 1527 & 110 & 4.940 \\
\hline & "self-directed groups" & 0 & 355 & 4 & 772 \\
\hline & "self-managing teams" & 89 & 4254 & 152 & 10.600 \\
\hline & "self-managing groups" & 1 & 224 & 9 & 647 \\
\hline \multicolumn{2}{|c|}{ „teamwork" } & 6.854 & 236.267 & 8.060 & 206.000 \\
\hline
\end{tabular}

Source: own study based on: EBSCO and Google Scholar (http://www.bu.uz.zgora.pl/index.php/pl/e-zbiory/eds; 06.12.2018 - access date; https://scholar.google.pl/ - 12.12.2018 - access date) 
Authors who signaled the intended investigation of autonomous groups already in the title of their articles focused on issues such as: a relationship between teams and results of the company's business processes (Janz et al., 1997) or the development of new products (Patanakul et al., 2012), building teams in complex production configurations (Powell and Pazos, 2017), creating teams and leading them (Druskat and Wheeler, 2004; Karriker, 2005), trust in teams (Lawless and Sofge, 2013). They also analyzed them in the contexts of: a business organization (Stray et al. 2018), a flexible organization and knowledge management in an enterprise (Abraham, 2005), changes in the allocation of resources and tasks (Moody and Szczerba, 1999), communicating (Szczerbicki, 1993).

In explaining the essence of autonomous teams ${ }^{10}$, it should be pointed out they are sometimes defined as "teams in which the members are given the latitude to jointly decide how their work is to be done" (DeVaro, 2006, p. 6), who can "make decisions independently and work under very limited supervision" (Holpp, 2001, p. 20). Similar features of such teams were indicated by J. Lichtarski (2008, p. 155), who said of their participants that they "share work and coordinate their own activities, being jointly responsible for the course of the whole task". However, T. Cummings and Ch. Worley (2005, p. 341; cf. Batt and Doellgast, 2005) noted that members of autonomous teams not only have an impact on the division of labor and the choice of working methods, but are also responsible for the overall or partial process of developing a product or a service. A similar stance is held by B. Mikuła (2000, p. 218), who argues that the function of such teams is to implement a number of related tasks, forming a whole throughout the work process. Members of these teams plan their activities, organize and coordinate work within the team, monitor its results and are jointly responsible for fulfilling tasks (cf. Bombala, 2011; Janowska, 1984). Important features that should characterize autonomous teams are: (partial) self-management, stimulating engagement and motivating members through participation, recognition and belonging to the team, boosting morale, promoting teamwork, responsibility for a specific process, product, service or group of clients, transparent control management systems, conducting audits to ensure the continuity of the self-management process, perceiving colleagues as shareholders who work towards the common good of the team/organization (Junior and Novaski, 2011).

10 Autonomy (independence) is defined in Słowniku języka polskiego PWN, among others, as: "the right of a community to settle their own internal affairs" and "independence and sovereignty in deciding about oneself (https://sjp.pwn.pl/sjp/autonomia;2551312.html, 05.03.2018 - access date). 
The specifics of such teams means that their participants cannot remain passive, but should actively participate in achieving the organization's goals. At the same time, they enjoy a high degree of autonomy, having a real impact on the conditions and manner of fulfilling tasks, as well as managing work environment - including not only choosing colleagues, but also deciding on work principles, tasks or the order of their performance (Krawczyk, 2013; cf. Mikuła and Potocki, 1997). An important factor in the effective functioning of autonomous teams is therefore the engagement of their members.

The concept of autonomous teams was presented to the Board and a joint decision was made to implement it. In the following section, the process and preliminary findings of creating such teams in the analyzed nonprofit entity were presented.

\section{Implementation of the concept of autonomous teams at SPOzZD}

In implementing the concept of autonomous teams in the Association, the procedure proposed by B. Mikuła and A. Potocki (1997, pp. 119-122) was used, including the following stages: 1 . Identifying the possibilities of implementing autonomous teams, 2. Basic preparation of staff, 3. Developing a new work organization model and choosing team members, 4. Training employees, 5. Implementing the new work organization, 6 . Monitoring and improving the new work organization.

During the implementation of the first stage, it is crucial to evaluate the possibility of appointing such teams in an organization and identifying possible factors that may constitute barriers to their functioning. It is important to take into account not only organizational, technical and technological limitations, but also those pertaining to human resources. Research results pointed to a resistance in members of the Association towards assuming responsibility and a self-reported insufficiency in terms of professional skills [both "hard" (technical) and "soft" (interpersonal)] necessary to carry out tasks. Nevertheless, it was considered that these are not a significant obstacle to the implementation of the concept. During the briefing and training meeting (as proposed by the abovementioned authors in the second stage $\left.{ }^{11}\right)$, the need for changes in the Association's activity was announced and - anticipating the concerns of the team

11 This was to reduce doubts in potential team members and prevent their reluctance (emotional, rational, social and/or political) to planned changes. 
members - it was explained that the implemented restructuring should be seen as a kind of "experiment" which will be interrupted in case of failure. At the same time, it was reported that its primary goal is to overcome the passivity of the members and to engage them in the activities which benefit the common good. This information consoled future participants of the study and positively geared them towards the proposed changes - they recognized that the implementation of appointing autonomous teams was in fact possible. Having had all members of the Association accept the proposal, the specifics of the implemented concept and the rules for autonomous teams were laid out during the same meeting. However, the full name "autonomous teams" was not used due to its formal overtone, having been replaced instead by the term "project teams" (or “working groups" in English). This was to avoid a potential suspicion of the members towards the "scientific approach" and to appeal to their intuitive understanding of the work carried out by autonomous teams.

Continuing the preparation of autonomous teams at the Association, the same meeting also reviewed the areas of the organization's operations and previous activity. Some of these initiatives were implemented annually (e.g. Christmas market, St. Nicholas' Day, picnics, trips, summer and winter rehabilitation and integration camps, charity events for the Association, celebration of the World Day of Persons with Down Syndrome), while some required constant engagement, e.g. plastic caps collection, actions undertaken within the Support Group, the 1\%-tax claim campaign, searching for sponsors, organizing hands-on sports activities for younger and older children (e.g. music therapy, performing arts, swimming pool), and meetings with medical-care specialists (e.g. endocrinologists, thematic conversations with specialists, etc.), website administration (FB, Support Groups, the Association's website). It was considered that each project team should handle one of the above areas.

In the next (third) stage, a new work organization model was developed, in line with the guidelines set out by B. Mikuła and A. Potocki, who pointed out the necessity of: identifying and describing the work processes for each group ${ }^{12}$,

12 When dividing the work into sections of activities assigned for fulfillment to autonomous teams, due to the recurring complexity of the processes being carried out, three basic ways of organizing the connections of individual teams may be useful: the serial group method, the parallel group method, the branched group method. The first is to divide the work process into several episodes. The division criterion is traceability in terms of the quantity and quality of work results (this criterion also applies in two subsequent methods). The team should identify their effort with the specific effect of the work and feel its meaning. Thus, the stands where work has been

Autonomous teams as a way to increase the engagement of nonprofit members 
establishing the expected scope of autonomy, size of teams, qualification requirements for their members, defining labor standards and measures necessary for implementing tasks, preparing changes in the organization's documentation, and developing organizational regulations for individual teams.

First, each member of the Association was offered an opportunity to become engaged in one of the teams, taking into account their preferences previously declared in the survey. Most people offered help in organizing the Christmas market, while every third member expressed willingness to participate in collecting plastic caps. Significantly fewer people were interested in pursuing activities in other areas (as presented in the fourth stage). Noting there are no volunteers to get involved in some of the areas ${ }^{13}$, participants were asked to verify their preferences and possibly switch from a different activity. They were given time to decide on it until the next working meeting, which was scheduled for one month ahead. It was during that second meeting that that composition of individual teams was finally determined. Several members decided to change their preferred activity, and thanks to that, there were "only" three areas without enough human resources: 1 . organization of trips (e.g. a oneday spring excursion), 2. organization of charity events for the Association, 3. organization of celebrations on the occasion of the World Day of Persons with Down Syndrome. The reluctance to engage in these areas sprang primarily from the anticipated large time expenditure, the need to show initiative, efficiency, creativity and the ability to establish and maintain interpersonal relationships. It was decided that activities in this area would be temporarily suspended, and if there is a need to perform any of the above tasks, another attempt will be made to appoint relevant teams.

In order to facilitate the functioning of newly created teams, the stages of implementation of tasks assigned to the teams were separated and their distribution was divided among the members. The person coordinating the course of work (President of the Association, the initiator of the restructuring),

carried out so far are combined to form groups. The product of one autonomous group becomes the subject of the next. The method of parallel autonomous groups consists in the creation of several teams whose work result is the same product. The tasks of each group are identical and the teams are independent of each other. Lastly, the branched method assumes that each group develops a different product which is part of the final product (cf. Mikuła and Potocki, 1997).

13 These areas were: organization of celebrations on the occasion of the World Day of Persons with Down Syndrome, summer rehabilitation and integration trip, and meetings with medical-care specialists. 
adhering to the recommendations of $\mathrm{B}$. Mikuła and $\mathrm{A}$. Potocki ${ }^{14}$, did not interfere in the emerging division of roles, and only provided advice on the necessary work that would determine the successful completion of individual tasks. This meeting resembled, in a sense, training ${ }^{15}$ (fourth stage), given that the coordinator and people actively working for the Association so far shared their knowledge and experience with other participants, also expressing willingness to help in those cases where members of individual teams will not be able to deal with the implementation of tasks. It was pointed out that, in such cases, team members would first try to solve the problems by themselves and seek help only as a last resort. It was supposed to evoke in them a sense of responsibility, engagement and authorship - this occurred in five teams.

The fifth stage (implementation of the new work organization) commenced in the last quarter of 2017. The Board was aware that the success of this stage depends on the engagement of the team members. Even if small at first, over time the opportunity to participate in important decisions concerning the whole organization, increasing sense of responsibility for the final outcome, may trigger a change in attitude among team members and this make them more actively engaged. Among other things, it was this argument that decided about the implementation of autonomous teams in the Association, serving to spark and boost their engagement so that they not only more often show concern for the future of the organization, but also begin to identify with its mission and goals, and therefore successfully carry them through for the common good.

Initially, team members showed helplessness, out of habit, expecting specific guidelines, support and advice from the President of the Association. When they did not receive it, they gradually began to show increasing autonomy. For example, members of the team responsible for organizing the stand at the Christmas Fair coped by themselves with the tasks, requiring only a few instances of guidance. The course and effects of their engagement were posted on the Association's

14 Leader in such teams cannot be selected by superiors, while all „decisions regarding pace and time of work, planning and division of work, the way of carrying out activities, exchange or transfer of group members, appointing a new leader (always for a definite period of time), are to be made democratically by members of the group at meetings, of course within the scope of autonomy granted and contained in the organizational regulations for a given group" (Mikuła and Potocki, 1997, p. 122).

15 More detailed and comprehensive training involving more techniques was not possible due to financial limitations, as well as time constraints (difficulties in scheduling meetings where all members of the Association could meet).

Autonomous teams as a way to increase the engagement of nonprofit members 
FB website and fan page, which was to motivate the remaining teams. Time will tell how effective this strategy will have proved. The tasks associated with the functioning of the Association are mostly cyclical and seasonal. So far, the autonomy and engagement has been observed in teams responsible for: the organization of a winter and summer rehabilitation and integration camp, hands-on sports activities for younger and older children, and collecting caps. According to the estimates of the Board of the Association, about $10 \%$ of members have so far shown increased engagement - they have independently planned the team's activities, organized and coordinated its work, and analyzed the obtained results. They were also willing to accept responsibility and show initiative in generating ideas. They communicated better with each other, developing their team-work skills. However, the full picture will only emerge after a year or so of experience with the new work organization.

Currently, it is not possible to say how much the implementation of the concept of autonomous teams at the Association will ultimately improve engagement. Further research is planned to be carried out following the period of at least one year of the Association's activity under the revised work rules. The study, along with an analysis of the effects and possible directions of further modifications, will be published in the subsequent article.

\section{Conclusion}

In the literature on management, engagement (involvement, commitment) is generally discussed in the context of cooperation with paid employees (e.g. Harter et al., 2002; Łochnicka, 2015; Maslach and Leiter, 2008; Schaufeli and Salanova, 2007; Vance, 2006). However, this article focused on the rarely analyzed problem, which is encouraging engagement in members of nonprofit organizations. The research conducted in the Association of Friends of Persons with Down Syndrome (Polish: SPOzZD) found reluctance of members to join in the implementation of the organization's statutory objectives. In response to the identified deficits, and taking into account the specific functioning of the analyzed entity and the concepts of various authors addressing the issue of engagement, a work reorganization scheme was developed and implemented creating autonomous teams ${ }^{16}$, responsible for the implementation of particular

16 A case study on the implementation of autonomous teams in a business organization was conducted, e.g. by A. Jaworska (2014). 
types of the Association's activity. Interestingly, this concept can be applied in every type of organization (Krawczyk, 2013), whether commercial or not.

By appointing autonomous groups the engagement of members of the organization was hoped to be increased, and so was their active attitude, mutual communication and interpersonal relationships; the goal was also to improve their job satisfaction ${ }^{17}$, arouse the conviction that for the good of their pupils they are capable of achieving the goals they have so far considered too difficult and demanding too great a number of skills, which - in their opinion - they did not possess. Consequently, this was to improve the effects of the Association's activity. Based on the interviews with Management Board members, it appears that until now the change in the way of carrying out tasks in the Association has resulted in increased involvement for $10 \%$ of members. The next results are expected to be reported later this year (2019), which is due to the seasonal character of events in the organization.

Given the limitations of the case study method, the obtained research results should not be generalized. However, the findings can nonetheless provide a hint for managers of associations or foundations with similar characteristics. It is indispensable for such organizations to rely on comparable resources and have a similar organizational structure, functioning under similar conditions (Grzegorczyk, 2015). It should be stressed, however, that even in organizations only partially similar to the one investigated in this paper, the presented procedure of using the case study method for research and analytical purposes, and above all practical ones, may be an inspiration to undertake similar research aimed at finding solutions to everyday problems.

\section{Summary}

\section{Autonomous teams as a way to increase the engagement of nonprofit members (case study)}

In the literature on management, engagement is generally discussed in the context of cooperation with paid employees. This article focuses on the rarely analyzed issue - developing the engagement of nonprofit members. Research was carried out on this subject in the association in Zielona Góra, where deficits were found in that area. The aim of the article is to determine the reasons

17 Similar benefits were indicated, among others, by S.A. Franforter and S.L. Christensen (2005), as well as R. Krawczyk (2013), although they referred to commercial entities. 
for the low engagement among SPOzZD members, to identify their expectations towards the functioning of the Association as well as to indicate activities that could encourage further engagement of these members, which can be implemented by representatives of the Board. The case study method was used.

Keywords: nonprofit organizations, associations, engagement.

\section{Streszczenie}

Autonomiczne zespoły jako sposób na zwiększenie zaangażowania członków organizacji non-profit (studium przypadku)

$\mathrm{W}$ literaturze przedmiotu z zakresu zarządzania, zaangażowanie jest na ogół omawiane w kontekście współpracy z pracownikami płatnymi. W niniejszym artykule skoncentrowano się na rzadko analizowanym zagadnieniu - rozwijaniu zaangażowania członków organizacji non profit. Zrealizowano badania na ten temat w zielonogórskim stowarzyszeniu, $\mathrm{w}$ którym stwierdzono deficyty $\mathrm{w}$ tym obszarze. Celem artykułu jest: ustalenie przyczyn niskiego zaangażowania członków SPOzZD, identyfikacja oczekiwań tych osób w zakresie funkcjonowania analizowanego Stowarzyszenia, a także wskazanie działań sprzyjających zwiększeniu zaangażowania wspomnianych członków, które mogą zostać zrealizowane przez przedstawicieli Zarządu omawianego podmiotu non profit. Posłużono się metodą case study.

\section{Słowa}

kluczowe: organizacje non profit, stowarzyszenia, zaangażowanie.

JEL

Classification: J24, L31, O15

\section{References}

1. Abraham, J. (2005). Modes d'organisation flexibles et management des connaissances. Le cas des Equipes Autonomes. Dans Gestion 2000: ManagementEProspective Gestion 2000, Vol.22, Iss.3, pp.15-34.

2. Akingbola, K., van den Berg, H. A. (2019). Antecedents, Consequences, and Context of Employee Engagement in Nonprofit Organizations. Review of Public Personnel Administration, Vol. 39(1), pp. 46-74. DOI: 10.1177/0734371X16684910. 
3. Alfes, K., Shantz, A., Bailey, C. (2016). Enhancing Volunteer Engagement to Achieve Desirable Outcomes: What Can Non-profit Employers Do? Voluntas, Vol. 27, Iss. 2, pp. 595-617, DOI: 10.1007/s11266-015-9601-3.

4. Anitha, J. (2014). Determinants of employee engagement and their impact on employee performance. International Journal of Productivity and Performance Management, Vol. 63, No 3, pp. 308-323, https://doi.org/10.1108/ IJPPM-01-2013-0008.

5. Batt, R., Doellgast, V. (2005). Groups, Teams, and the Division of Labor: Interdisciplinary Perspectives on the Organization of Work. In: Ackroyd, S., Batt, R., Thompson, P., Tolbert, P., The Oxford Handbook of Work and Organization, New York: Oxford University Press.

6. Bombała, B. (2011). Od humanizacji i strukturalizacji pracy do upełnomocniania pracowników - aspekt etyczny. Annales. Etyka w życiu gospodarczym, Vol. 14, No. 1, pp.67-81.

7. Croston, D. (2008). Employee Engagement "The People First" Approach to Building a Business, Sydney: Moonstone Media.

8. Cummings, T., Worley, Ch. (2005). Organization Development and Change, Mason: South-Western College Pub.

9. Czakon, W. (2006). Łabędzie Poppera - case studies w badaniach nauk o zarządzaniu. Przegląd Organizacji, No. 9, pp. 9-12.

10. Czakon, W. (2015). Zastosowanie studiów przypadku w badaniach nauk o zarządzaniu, In: Czakon W. (ed.). Podstawy metodologii badań w naukach o zarządzaniu (pp. 189-210). Warszawa: Wolters Kluwer.

11. DeVaro, J. (2006). Teams, autonomy, and the financial performance of firms, http:/ / digitalcommons.ilr.cornell.edu/articles/107/ (12.12.2018 - access date).

12. Dondajewska, A. (2016). Studia przypadków w badaniach nauk o zarządzaniu w świetle rygoru metodologicznego. Zeszyty Naukowe Politechniki Poznańskiej, Nr 70, Organizacja i Zarządzanie, pp. 39-50. DOI: 10.21008/j.0239-9415.2016.070.03.

13. Druskat, V., Wheeler, J. (2004). How to lead a self-managing team. MIT Sloan Management Review, Vol. 32, https://sloanreview.mit.edu/.../howto-lead-a-selfmanaging-team/ (13.12.2018 - access date).

14. Franforter, S.A., Christensen, S.L. (2005). Finding competitive advantage in self-managed teams. Business Forum, Vol. 27, pp. 20-24.

15. Freeborough R., Patterson K., (2015). Exploring the Effect of Transformational Leadership on Nonprofit Leader Engagement. Servant Leadership: Theory and Practice, Vol. 2, Iss. 1, pp. 49-70.

16. Gruman, J.A., Saks, A.M. (2011). Performance management and employee engagement. Human Resource Management Review, Vol. 21, Iss. 2, pp. 123136, https://doi.org/10.1016/j.hrmr.2010.09.004.

17. Grzegorczyk, W. (2015). Studium przypadku jako metoda badawcza $i$ dydaktyczna w naukach o zarzadzaniu. In: Grzegorczyk, W. (ed.). Wybrane problemy zarządzania $i$ finansów. Studia przypadków (pp. 9-16). Łódź: Wydawnictwo Uniwersytetu Łódzkiego.

18. Harter, J., Schmidt, F., Hayes, T. (2002). Business-unit level relationship between employee satisfaction, employee engagement, and business outcomes: a meta-analysis. Journal of Applied Psychology, Vol. 87, pp. 268-279. 
19. Holpp, L. (2001). Jak kierować zespołami. Warszawa: Wydawnictwo RM.

20. https://sjp.pl/zaangazowac+ (23.05.2018 - access date).

21. https://sjp.pwn.pl/sjp/autonomia;2551312.html (05.03.2018 - access date).

22. Janowska, Z. (1984). Organizacyjne formy humanizacji pracy produkcyjnej. Warszawa: PWE.

23. Janz, B.D., Wetherbe, J.C., Davis, G., Noe, R.A. (1997). Reengineering the Systems Development Process: The Link between Autonomous Teams and Business Process Outcomes. Journal of Management Information Systems, Vol. 14(1), pp. 41-68.

24. Jaworska, A. (2014). Autonomiczne zespoły pracownicze w epoce ponowoczesności, In: Walczak-Duraj, D., Kutyło Ł. (eds.). Nowe formy pracy $i$ zatrudnienia w perspektywie humanistycznej (pp. 31-49). Humanizacja Pracy. Płock: Szkoła Wyższa im. Pawła Włodkowica w Płocku.

25. Juchnowicz, M. (2010). Zarzadzanie przez zaangażowanie. Koncepcja. Kontrowersje. Aplikacje. Warszawa: PWE.

26. Junior, L.A., Novaski, O. (2011). Semi-Autonomous Work Team Implementation in Manufacturing Cells Using a Simplified Project Management. Business and Economics Journal, June, pp. 1-11.

27. Karriker, J.H. (2005). Cyclical group development and interaction-based leadership emergence in autonomous teams: an integrated model. Journal of Leadership \& Organizational Studies, Vol. 11, Iss. 4, pp. 54-64. DOI: $10.1177 \% 2 F 107179190501100405$.

28. Kochan, T.A., Dyer, L. (1993). Managing transformational change: the role of human resource professional, International Journal of Human Resource Management, No. 4, pp. 569-590, 10.1080/09585199300000037.

29. Krawczyk, R. (2013). Autonomiczne grupy pracownicze jako nowoczesna forma zarządzania przedsiębiorstwem. Zarządzanie i Finanse, No. 1, pp. 359-370.

30. Lawler, E. (1994). Total quality management and employee involvement: are they compatible?. The Academy of Management Executive, No. 8(1), pp. 68-76.

31. Lawless, W., Sofge, D. (2013). Trust and Interdependence in Controlling Multi-Agent Multi-Tasking Autonomous Teams, AAAI Spring Symposium, https://www.aaai.org/ocs/index.php/SSS/SSS13/ paper/.../6005 (12.12.2018 - access date).

32. Lichtarski, J. (2008). Istota i typologia zespołów zadaniowych. Prace Naukowe Uniwersytetu Ekonomicznego we Wroctawiu, No. 24, pp. 149-158.

33. Łochnicka, D. (2015). Zaangażowanie pracownicze jako determinanta rozwoju organizacji, Studia Prawno-Ekonomiczne, T. XCIV, pp. 317-334.

34. Macdonald, E., Herrman, H., Hinds, P., Crowe, J., McDonald, P. (2002). Beyond interdisciplinary boundaries: views of consumers, carers and non-government organizations on teamwork. Australasian Psychiatry, Vol. 10, Iss. 2, pp. 125-129. DOI: 10.1046/j.1440-1665.2002.00420.x.

35. Macey, W.H., Schneider, B. (2008). Meaning of Employee Engagement. Industrial and Organizational Psychology, No. 1, pp. 3-30. 
36. Maslach, C., Leiter, M. (2008). Early predictors of job burnout and engagement, Journal of Applied Psychology, Vol. 93(3), pp. 498-512.

37. Meyer, J., Allen, N. (1991). A Three-Component Conceptualization of Organizational Commitment, Human Resource Management Review, No. 1, pp. 61-89.

38. Mikuła, B. (2000). Człowiek i organizacja, Humanizm w koncepcjach i metodach organizacji i zarzadzania XX wieku. Kraków: Antykwa.

39. Mikuła, B., Potocki, A. (1997). Metody zarządzania innowacyjnopartycypacyjnego, Kraków-Kluczbork: Antykwa.

40. Moody, J., Szczerba, R. (1999). A novel architecture for resource allocation and task execution among autonomous teams, IEEE SMC'99 Conference Proceedings 1999 IEEE International Conference on Systems, Man \& Cybernetics (Cat No99CH37028), Iss. 1, pp. 22-27.

41. Mrówka, R. (2010). Pojęcie zaangażowania pracowników we współczesnych naukach ekonomicznych i praktyce gospodarczej, In: Bartkowiak, R., Ostaszewski, J. (eds.), Nauki ekonomiczne w świetle nowych wyzwań gospodarczych (pp. 405-416). Warszawa: Oficyna Wydawnicza SGH.

42. Mullins, J. (2005). Management and Organisational Behaviour. New York: Prentice Hall/Financial Times.

43. Park, S., Kim, J., Park, J., Lim, D.H. (2018). Work Engagement in Nonprofit Organizations: A Conceptual Model. Human Resource Development Review, Vol. 17(1), pp. 5-33, DOI: 10.1177/1534484317750993.

44. Patanakul, P.; Chen, J.; Lynn, G.S. (2012). Autonomous Teams and New Product Development Autonomous Teams and New Product Development, Journal of Product Innovation Management. Vol. 29, Iss. 5, pp. 734-750. DOI: 10.1111/j.1540-5885.2012.00934.x.

45. Powell, A.W., Pazos, P. (2017). Building High-Performing Autonomous Teams in Complex Manufacturing Settings: A Naturalistic Research Approach. Engineering Management Journal, Vol. 29, Iss. 3, pp. 206-219. DOI: $10.1080 / 10429247.2017 .1324244$.

46. Pun, K., Chin, K., Gill, R. (2001). Determinants of Employee Involvement Practices in Manufacturing Enterprises. Total Quality Management, Vol. 12(1), pp. 95-109.

47. Purcell, J. (1993). The challenge of human resource management for industrial relations research and practice. International Journal of Human Resource Management, No 4, pp. 511-527. DOI: 10.1080/09585199300000034.

48. Robbins, S.P., Judge, T.A. (2013). Organizational Behaviour. New York: Prentice Hall.

49. Robinson, D., Perryman, S., Hayday, S. (2004). The Drivers of Employee Engagement Report. Brighton: Institute for Employment Studies.

50. Salanova, M., Agut, S., Peiró, J. M. (2005). Linking Organizational Resources and Work Engagement to Employee Performance and Customer Loyalty: The Mediation of Service Climate. Journal of Applied Psychology, Vol. 90, pp. 1217-1227, DOI: 10.1037/0021-9010.90.6.1217.

51. Schaufeli, W.B., Bakker, A.B. (2003). UWES Utrecht work engagement scale. Preliminary manual, Version 1, November, Occupational Health Psychology Unit, Utrecht: Utrecht University. 
52. Schaufeli, W.B., Salanova, M. (2007). Work engagement. An emerging psychological concept and its implications for organizations. Managing Social and Ethical Issues in Organizations, No. 5, pp. 135-177.

53. Scholl, R., What is Organizational Commitment?, The University of Rhode Island; http://www. uri.edu/research/lrc/scholl/webnotes/ Commitment.htm (19.12.2018 - access date), state by day $6^{\text {th }}$ of June, 2014.

54. Skorek, N., Trojanowski, M., Wilczak, A. (2010). Studium przypadku w nauczaniu marketingu. Marketing w realiach wspótczesnego rynku. Strategie i dziatania marketingowe. Warszawa: PWE.

55. Skowron-Mielnik, B. (2014). Budowanie zaangażowania pracowników $\mathrm{w}$ proces doskonalenia przedsiębiorstwa $\mathrm{z}$ wykorzystaniem employer branding. Management Forum, No 4, pp. 25-38.

56. Smythe, J. (2009). CEO - dyrektor do spraw zaangażowania. Warszawa: Oficyna a Wolters Kluwer Business.

57. Soane, E., Truss, C., Alfes, K., Shantz, A., Rees, C., Gatenby, M. (2012). Development and application of a new measure of employee engagement: the ISA Engagement Scale. Human Resource Development International, Vol. 15, Iss. 5, pp. 529-547, DOI: 10.1080/13678868.2012.726542.

58. Sofijanova, E., Zabijakin-Chatleska, V. (2013). Employee involvement and organizational performance: evidence from the manufacturing sector in republic of Macedonia. Trakia Journal of Sciences, Vol. 11, Suppl. 1, pp. 31-36.

59. Stankiewicz, J., Bortnowska, H., Seiler, B. (2018). Wzbudzanie i rozwijanie zaangażowania wolontariuszy $w$ organizacjach non profit przez mentoring. Organizacja i Kierowanie, No 4, pp. $11-35$.

60. Stankiewicz, J., Moczulska, M. (2014), Zaangażowanie pracowników i jego "druga strona" : pracoholizm i wypalenie zawodowe. Przeglad Organizacji, No. 2, pp. 25-30.

61. Stray, V., Moe, N., Hoda, R. (2018). Autonomous agile teams: Challenges and future directions for research, https://arxiv.org/abs/1810.02765 (12.12.2018 - access date).

62. Szczerbicki, E. (1993). Functioning of autonomous groups: the role of delayed information. International Journal of Systems Science, Vol. 24, Iss. 7, pp. 1275-1284. DOI: 10.1080/00207729308949559.

63. Torrington, D., Hall, L., Taylor, S., Atkinson, C. (2002). Human Resource Management. International edition. Prentice Hall/Financial Times.

64. Vance, R. (2006). Employee Engagement and Commitment. A Guide to Understanding, Measuring and Increasing Engagement in Your Company, Alexandria: SHRM Foundation. 